The Common Agricultural Policy of the European Union the present and the future

EU Member States

point of view 



\section{INSTITUTE OF AGRICULTURAL AND FOOD ECONOMICS NATIONAL RESEARCH INSTITUTE}

\section{The Common Agricultural Policy of the European Union - the present and the future}

\section{EU Member States point of view}

Editors:

dr Marek Wigier

prof. dr hab. Andrzej Kowalski

Proceedings of the International Scientific Conference

"The Common Agricultural Policy of the European Union - the present and the future" Multi-Annual Programme 2015-2019

"The Polish and the EU agricultures 2020+. Challenges, chances, threats, proposals" 5-7 December 2017 Stare Jabłonki, Poland

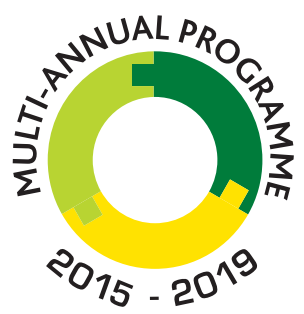

THE POLISH AND THE EU AGRICULTURES 2020+ CHALLENGES, CHANCES, THREATS, PROPOSALS

Warsaw 2018 
This monograph was prepared under the Multi-Annual Programme 2015-2019

"The Polish and the EU agricultures 2020+. Challenges, chances, threats, proposals".

The publication is a collection of selected papers delivered at the 22th edition of the International Scientific Conference organized by the Institute of Agricultural and Food Economics - National Research Institute. The theme of the conference was "The Common Agricultural Policy of the European Union the present and the future. The conference was placed on 5-7 December 2017 in Stary Jabłonki in Poland. Common Agricultural Policy was and still is one of the key pillars of European integration. Published in two volumes materials refer directly to the current and future of the CAP in EU and non EU member states, the strategic objectives and principles of agricultural policy for the agri-food sector and rural areas, address the issues of equilibrium between agriculture, forestry and land use, relate to the dilemmas for the EU budget and the CAP after 2020, CAP instruments and their adjustment, transformations of the rural economy and programming of the rural and agricultural policy, as well as productivity and production efficiency and tensions between sectoral action and between different models of territorial activities.

In the Scientific Committee of the Conference was participated: Prof. Andrzej Kowalski (IAFE-NRI, Poland), Prof. Drago Cvijanonivić (University of Kragujevac, Serbia), Prof. Thomas Doucha (IAEI, Czech Republic), Noureddin Driouech, PhD (CIHEAM, Italy), Prof. Szczepan Figiel (IAFE-NRI, Poland), Prof. Masahiko Gemma (Waseda University, Japan), Prof. Wojciech Józwiak (IAFE-NRI, Poland), Prof. Jacek Kulawik (IAFE-NRI, Poland), Prof. Yuriy Oleksiyovych Lupenko (IAE, Ukraina), Prof. Věra Majerová (CULS, Prague), Prof. Dimitre Nikolov (IAE, Bulgaria), Maire Nurmet, PhD (EMÜ, Estonia), Prof. Gabriel Popescu (ASE, Romania), Norbert Potori, PhD (AKI, Hungary), Prof. Włodzimierz Rembisz (IAFE-NRI, Poland), Piotr Szajner, PhD (IAFE-NRI, Poland), Prof. Alina Sikorska (IAFE-NRI, Poland), Prof. Jonel Subić (IAE, Serbia), Prof. Samuele Trestini (UNIPD, Italy), Prof. Olga Varchenko (Bila Tserkva National Agrarian University, Ukraine), Dipl.-Ing. Klaus Wagner (AWI, Austria), Marek Wigier, PhD (IAFE-NRI, Poland), Prof. Józef St. Zegar (IAFE-NRI, Poland)

In the Organising Committee of the Conference was participated: Małgorzata Bułkowska (IAFE-NRI, Poland), Anna Hankiewicz (IAFE-NRI, Poland), Joanna Jaroszewska (IAFE-NRI, Poland), Joanna Korczak (IAFE-NRI, Poland), Krzysztof Kossakowski (IAFE-NRI, Poland), Irena Mikiewicz (IAFE-NRI, Poland), Małgorzata Mikołajczyk (IAFE-NRI, Poland), Lech Parzuchowski (IAFE-NRI, Poland), Ewa Sierakowska (IAFE-NRI, Poland), Paulina Smakosz (IAFE-NRI, Poland), Leszek Ślipski (IAFE-NRI, Poland), Marek Wigier, PhD (IAFE-NRI, Poland).

Reviewers:

Professor Dimitre Nikolov, Institute of Agricultural Economics, Sofia, Bulgaria

Professor Gabriel Popescu, The Bucharest University of Economic Studies, Bucharest, Romania

Professor Samuele Trestini, University of Padva, Italy

Proofreader

Katarzyna Mikulska

Technical editors:

Joanna Jaroszewska, Barbara Pawtowska, Ewa Sierakowska, Kamila Tomaszewska,

Barbara Walkiewicz

Translated by

Summa Linguae S.A.

Cover Project

Leszek Ślipski

ISBN 978-83-7658-743-1

DOI: $10.30858 / \mathrm{pw} / 9788376587431$

Instytut Ekonomiki Rolnictwa i Gospodarki Żywnościowej

- Państwowy Instytut Badawczy

ul. Świętokrzyska 20, 00-002 Warszawa

tel.: (22) 5054444

faks: (22) 5054636

e-mail:dw@ierigz.waw.pl

http://www.ierigz.waw.pl 


\section{Contents}

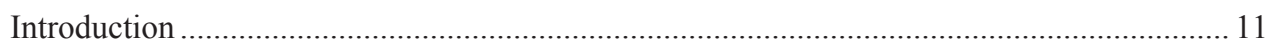

Dr Marek Wigier

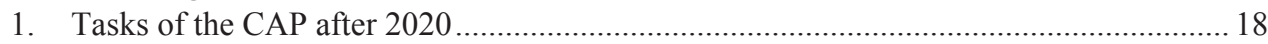

Dr hab. Julian Krzyżanowski

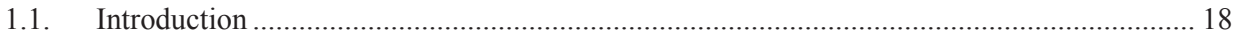

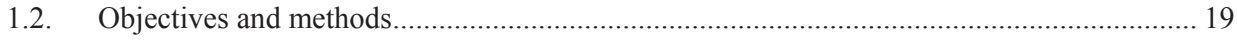

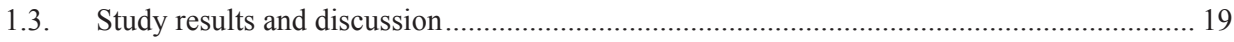

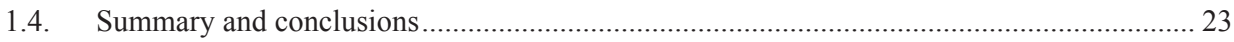

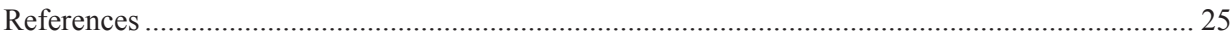

2. An assessment of the regional impacts of post-2020 CAP budgetary cuts on production

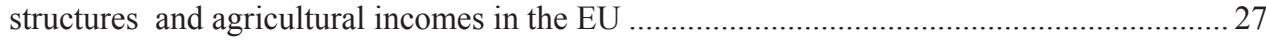

PhD Norbert Potori, PhD János Sávoly, PhD Szabolcs Biró

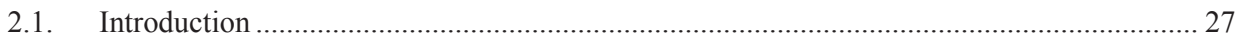

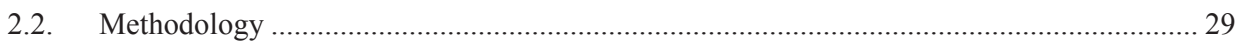

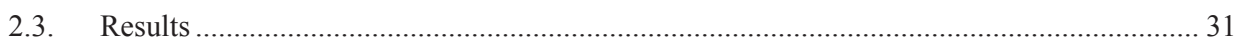

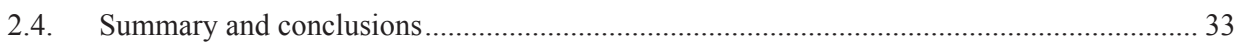

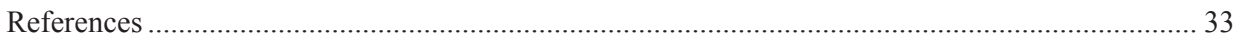

3. Is there room for financial instruments in the Common Agricultural Policy? Casus of

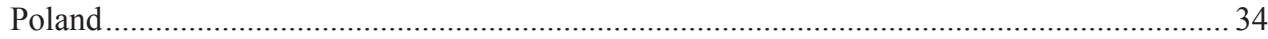

Prof. dr hab. Jacek Kulawik, PhD Barbara Wieliczko, PhD Michat Soliwoda

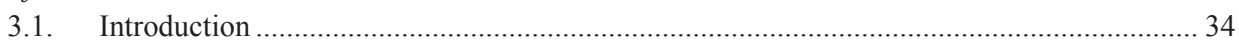

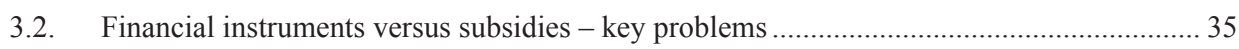

3.3. The use of financial instruments under the EU policy ......................................................... 37

3.4. Example of the use of FI in the 2014-2020 programming period ......................................... 38

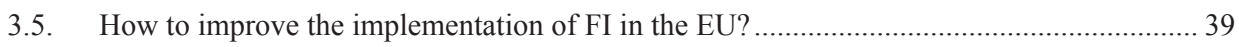

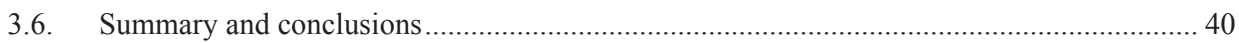

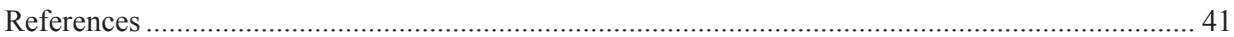

4. The past, present and future of the CAP - the Hungarian viewpoint ............................. 43

Dr Tamás Mizik

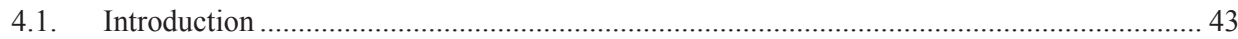

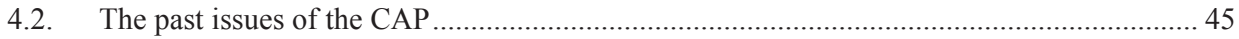

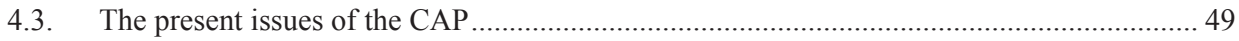

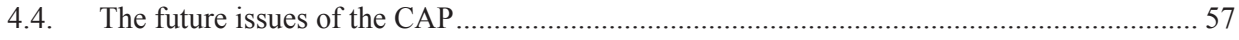

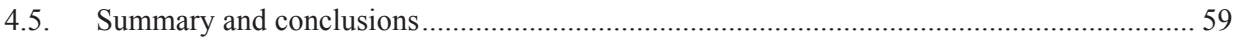

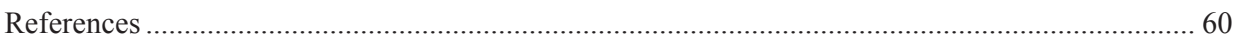


5. Going beyond the Rural Development Programme: a Master Plan for Austria's rural areas in the framework of the CAP

Dip.-Ing. Klaus Wagner

5.1. Introduction

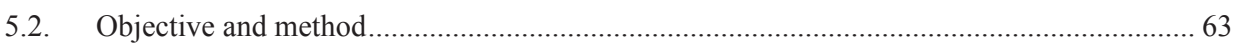

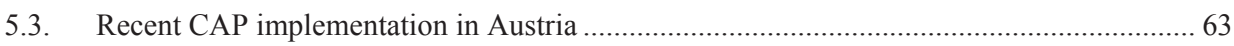

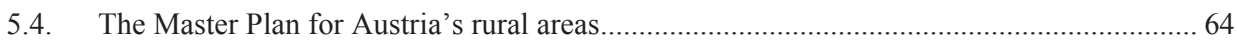

5.5. CAP in the system of the EU policy objectives and in the view of regional science

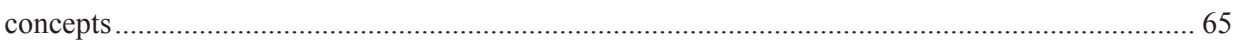

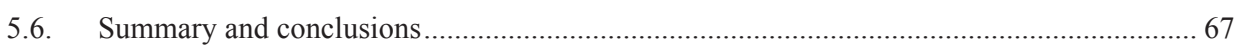

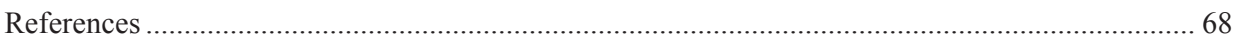

6. Possibilities to connect the Romanian agricultural research to the market requirements 69 Prof. Gabriel Popescu

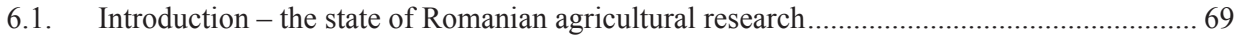

6.2. The problems faced by agricultural research since 1990 ..................................................... 71

6.3. Possible solutions for the recovery of Romanian agricultural research ................................ 76

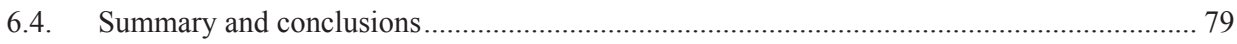

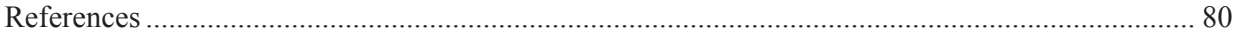

7. Price relationships of the production factors as exogenous determinants of production in agriculture.

Prof. dr hab. Włodzimierz Rembisz, PhD Adam Waszkowski

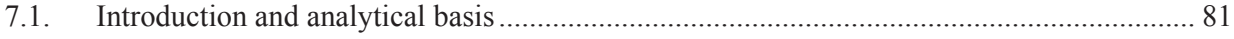

7.2. Relationships of prices of the capital, labour and land factors - hypothetical approach...... 83

7.3. Relationships of prices of the capital, labour and land factors - empirical approach .......... 84

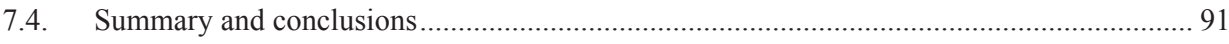

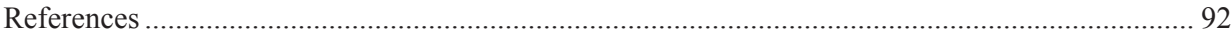

8. Effects of direct payments on agricultural development in Bulgaria ............................. 93 PhD Bozhidar Ivanov

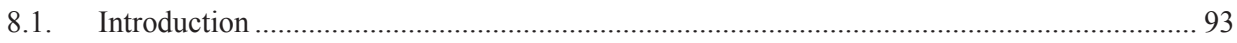

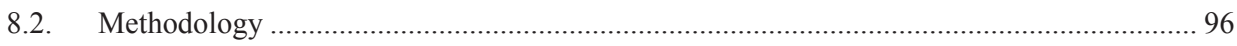

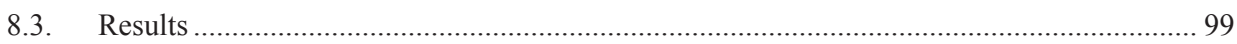

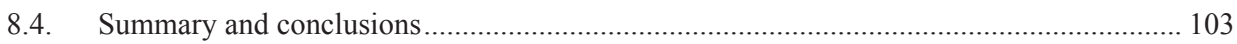

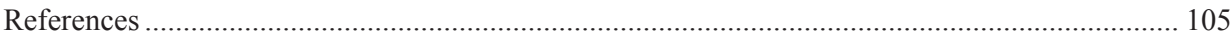

9. Re-adjusting risk management within the CAP: evidences on the implementation of the

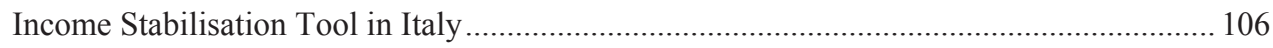
Prof. Samuele Trestini, PhD Elisa Giampietri

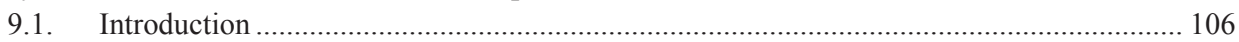

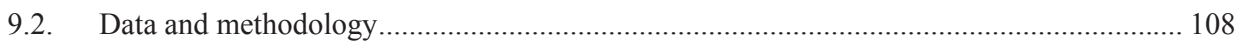




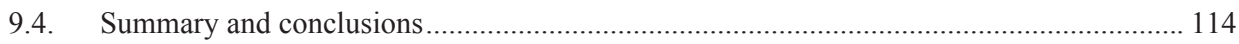

References

10. Comparison of risk management tools under the CAP of the EU, the US Farm Bill

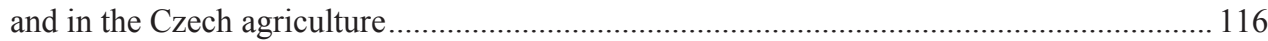
Ing. Václav Vilhelm, CSc., Ing. Sumudu Namali Gouri Boyinová, PhD Jindřich Špička

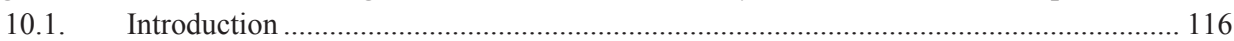

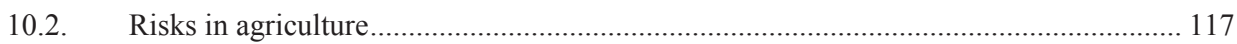

10.3. Risk management policy in the United States Farm Bill 2014 _..................................... 118

10.4. Risk management policy of the European Union's CAP ................................................ 119

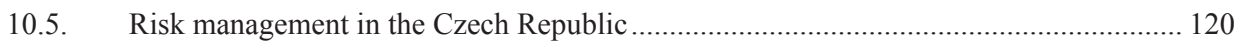

10.6. Comparative analysis of risk management policies ........................................................ 121

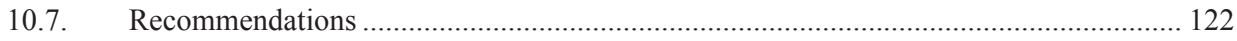

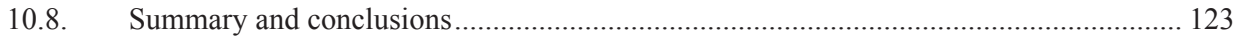

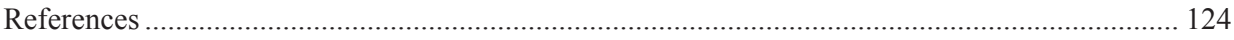

11. Factors determining the crop insurance level in Poland taking into account the level

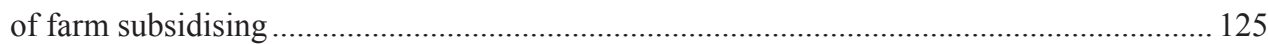

Prof. Adam Was, PhD Pawet Kobus

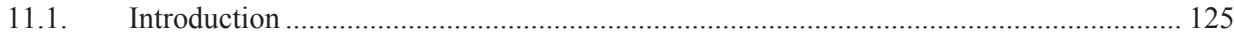

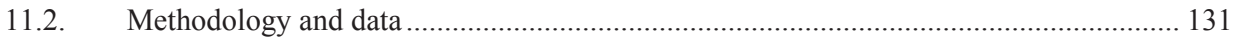

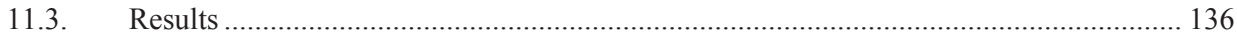

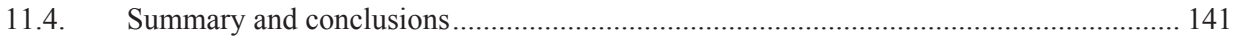

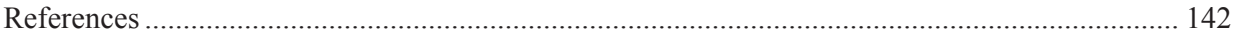

12. Farms and agricultural enterprises for development of sustainable and smart cooperatives: a multifactor approach using digital farm management ............................... 147 Prof. dr habil Adriana Mihnea, Prof. dr Dimitre Nikolov, dr Krasimir Kostenarov

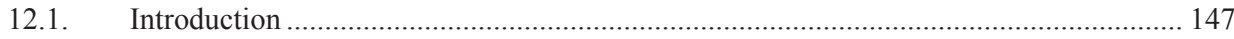

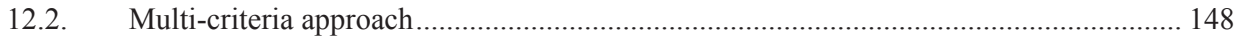

12.3. Construction of Farm Management Model ................................................................ 150

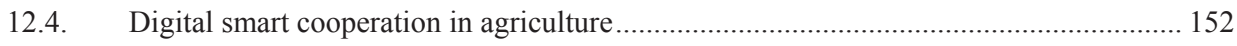

12.5. Application of the ANP Farm Management Model ....................................................... 154

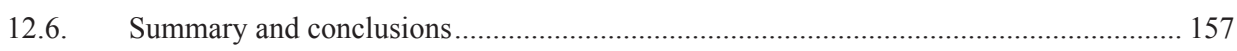

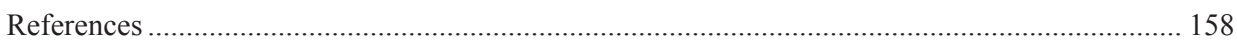

13. Brexit - potential implications for the Polish food sector .............................................. 159

Dr Katarzyna Kosior, Dr Łukasz Ambroziak

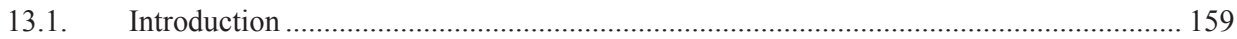

13.2. Negotiations on Brexit - what should be the model of the future relations? ..................... 161

13.3. The future of the EU finances and the CAP in the context of Brexit .............................. 163 
13.4. Impact of possible changes in the CAP budget on the net balance of Poland and transfers to the Polish agriculture.

13.5. The potential impact of Brexit on agri-food trade between Poland and the United

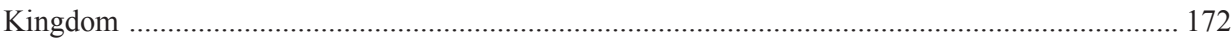

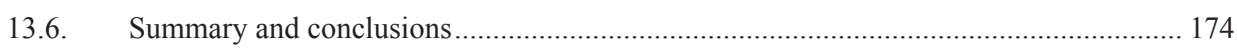

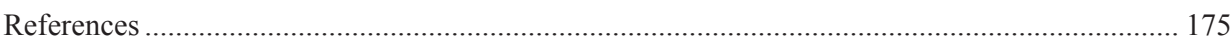

14. The Transatlantic Trade and Investment Partnership (TTIP): a threat or an opportunity for the EU-Mediterranean agriculture and agri-food sector? An exploratory survey ........... 177 Dipl.-Ing. Katja Pietrzyck, PhD Noureddin Driouech, Prof. Brigitte Petersen

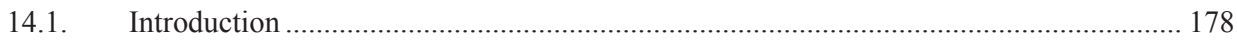

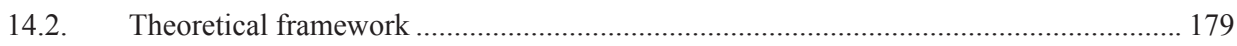

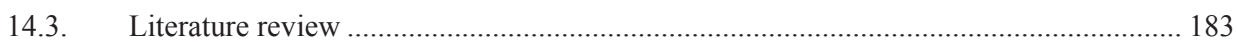

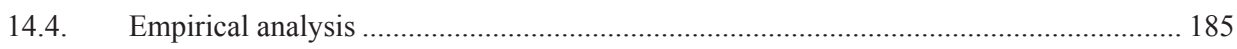

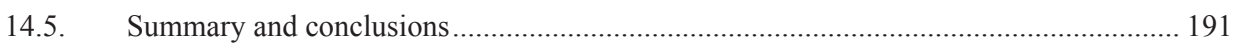

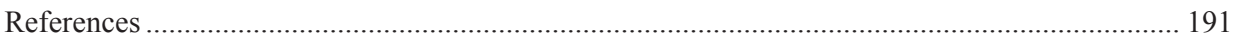

Appendix I: Overview of trade statistics regarding selected products ........................................... 195

15. The concept of short supply chains in the food economy............................................. 196

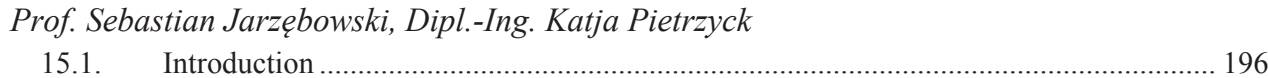

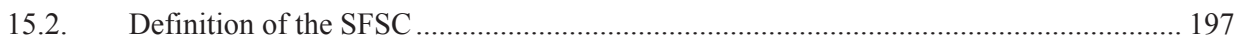

15.3. Development of short supply chains in Europe............................................................. 201

15.4. Global context of European short supply chains ........................................................... 205

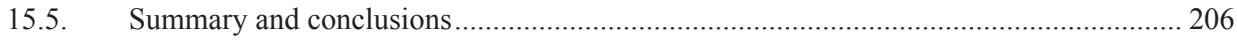

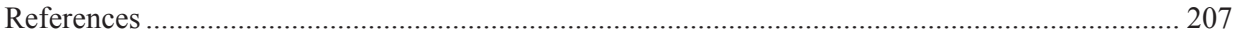

16. The CAP implementation in Wallonia - today performance and questions for the future -

A brief supplementary comment from Warmia and Mazury perspective............................. 209

PhD Philippe Burny, PhD Benon Gazinski

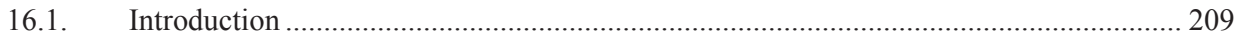

16.2. Implementation of the green payment in Wallonia in 2015 ........................................ 210

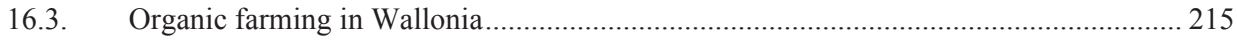

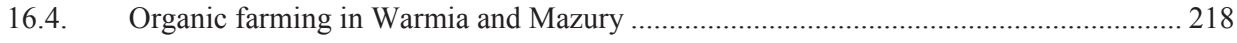

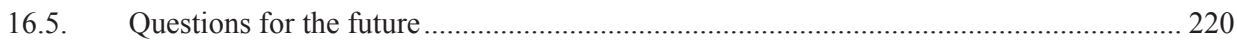

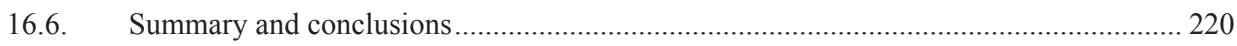

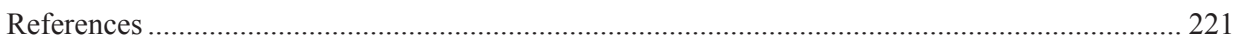

17. Afforestation of agricultural land financed from the RDP 2014-2020 ....................... 224

PhD Marek Zieliński

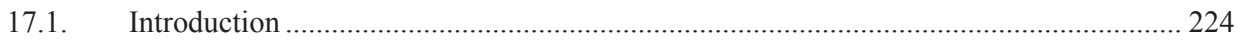

17.2. Natural farming conditions in Poland in regional terms................................................. 225 
17.3. The impact of natural farming conditions in Poland on the economic situation and the possibility of afforestation on farms

17.4. Land afforestation financed from the RDP 2014-2020 in regional terms

17.5. Importance of land afforestations financed under the RDP 2014-2020 in the EU climate policy for 2021-2030.

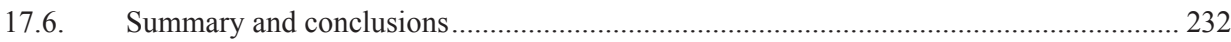

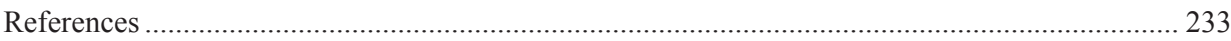

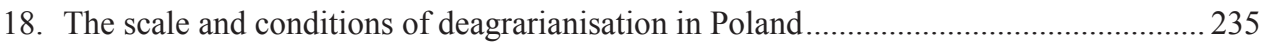

PhD Michat Dudek, PhD Bożena Karwat-Woźniak

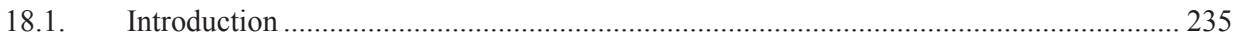

18.2. The conditions of the decrease in employment in agriculture ......................................... 236

18.3. The change in the scale of employment in agriculture in Poland and its conditions....... 238

18.4. The instruments of the Cohesion Policy and agriculture and rural development of the EU

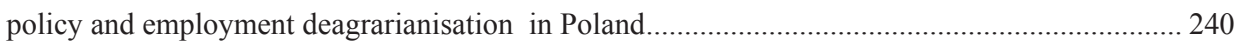

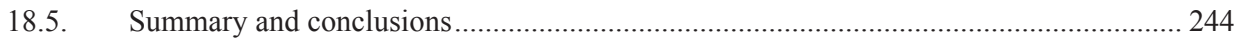

References 245

19. Socio-economic and environmental parameters and results of rural development under the CAP: the case of Bulgaria ................................................................................................ 247 Prof.dr.hab. Julia Doitchinova, Prof.dr.hab. Ivan Kanchev, Ass.Prof. Ralitsa Terziyska PhD, Ass.Prof. Kristina Todorova PhD

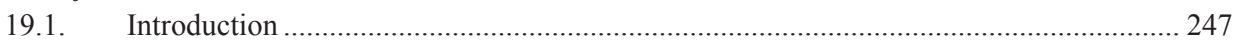

19.2. Changes in Bulgarian rural areas - socio-economic and environmental aspects................ 248

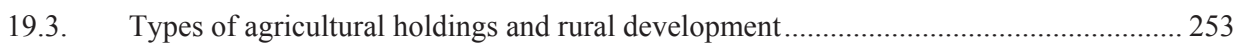

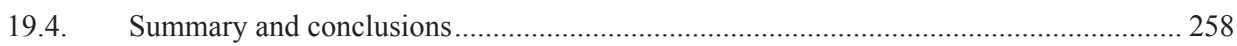

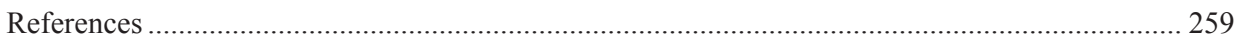

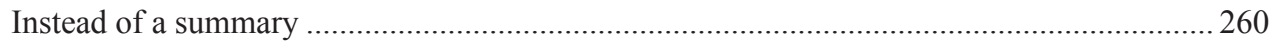

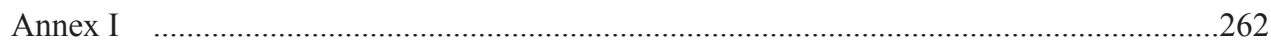




\title{
5. Going beyond the Rural Development Programme: a Master Plan for Austria's rural areas in the framework of the CAP
}

\author{
Dip.-Ing. Klaus Wagner \\ Federal Institute of Agricultural Economics, Vienna, Austria \\ klaus.wagner@awi.bmlfuw.gv.at
}

DOI: $10.30858 / \mathrm{pw} / 9788376587431.5$

\begin{abstract}
In each of the CAP periods the Austrian Rural Development Programmes have acquired a more integrative character. Starting with measures concerning farms, they have been enlarged with soil, biodiversity and water protection measures, then included also local developments, diversification beyond the agricultural sector and more general quality of life measures and in the recent period putting the focus on knowledge transfer, innovation and climate change. In continuation of this approach the Austrian Ministry of Agriculture has been the driver to create the Master Plan for Rural Areas, which was elaborated on the basis of a broad participation process and seeks to integrate economics, environment, administration, social life and responsibility, infrastructure, mobility and digitisation. Of course, there are many challenges in implementation, as for example the integrative character of objectives and measures faces governance structures based on conventional sectoral divisions. The concepts behind the CAP measures and strategies are discussed on the basis of regional science criteria.
\end{abstract}

Keywords: rural development, integrative development, agricultural policy, master plan

JEL codes: Q18, Q19, R58

\subsection{Introduction}

Since Austria's accession to the European Union (EU) it has used most of the possibilities provided by the Common Agricultural Policy (CAP) guidelines. In each of the CAP periods, the Austrian Rural Development Programmes have acquired a more integrative character. Starting almost only with measures concerning agricultural enterprises, the programmes have been extended with soil, biodiversity and water protection measures, including local developments, diversification beyond the agricultural sector, more general quality of life measures and, in the recent period, they have put the focus on knowledge transfer, innovation and climate change. In continuation of this approach and as an input to ideas and strategies for the next programming period, 
the Austrian Ministry of Agriculture has called for development of the Master Plan for Rural Areas, with a wider, more holistic and complex view of rural development.

\subsection{Objective and method}

The objective of this paper is to give a short overview of the CAP and especially rural development in the recent periods as background information and to understand the further step - the Master Plan for Rural Areas, which will be explained in a comprehensive form. In addition, the whole CAP approach will be questioned and discussed by means of regional science concepts - for example in Trippl et al. [2015] or Bökemann [1999] - which ask different questions than the evaluation of effects, impacts and efficiency in figures. This view shows possible polarities and conflicts of objectives, concepts or strategies.

\subsection{Recent CAP implementation in Austria}

From the beginning of the CAP in Austria in 1995, more funds were dedicated to the second pillar (rural development) than to the first pillar (direct payments, market organisation) - in contrast to the EU average payments. In the current 2014-2020 period, too, around two thirds of the budget is dedicated to the second pillar, with a huge rural development programme, while in the EU all the second pillar makes up only a quarter of the total CAP budget. Of the 140400 farms in the official Austrian statistics for 2013, 114000 received CAP payments in 2016 and are registered in the IACS [BMLFUW, 2017a]. All the farms received EUR 1.59 billion in 2016, an average payment of EUR 14000 per farm. The most important measures are direct payments, agri-environmentclimate payments (with 19 sub-measures), payments for areas facing natural or other specific constraints, followed by investments in physical assets, organic farming as well as basic services and village renewal.

Table 1. Most important CAP payments in Austria, 2016

\begin{tabular}{|l|c|c|}
\hline \multicolumn{1}{|c|}{ Measure } & \multicolumn{1}{|c|}{$\begin{array}{c}\text { Subsidy cases, } \\
\text { number }\end{array}$} & $\begin{array}{c}\text { Average payment } \\
\text { per subsidy case, EUR }\end{array}$ \\
\hline Direct payments (1 ${ }^{\text {st }}$ pillar) & 108567 & 6361 \\
\hline $\begin{array}{l}\text { Agri-environmental-climate } \\
\text { payments }\left(2^{\text {nd }} \text { pillar, M10) }\right.\end{array}$ & 91942 & 4425 \\
\hline $\begin{array}{l}\text { Areas facing natural or other spe- } \\
\text { cific constraints }\left(2^{\text {nd }} \text { pillar, M13) }\right.\end{array}$ & 83234 & 3130 \\
\hline
\end{tabular}

Source: BMLFUW, 2017 a. 


\subsection{The Master Plan for Austria's rural areas}

At the beginning of 2017, the Austrian Minister for Agriculture, Forestry, Environment and Water Management initiated the formulation of a Master Plan for the Rural Area. The background was the still unsatisfactory situation in rural regions. Despite many years of support for rural areas with a diverse set of measures, the general development lags behind urban or central regions. Austria's demographic development is characterised by strong growth in urban centres, while the population in rural areas is declining. In terms of education and career opportunities, moving to central hubs that are home to companies and educational institutions is appealing. But two thirds of Austrians still live in rural regions, and more than $50 \%$ of the population live in municipalities with less than 10000 inhabitants [BMLFUW, 2017b]. The importance and the potential of the rural areas is evident.

The process for the development of this Master Plan, as a strategic paper for development, involved 200 experts, 2000 citizens and comprised more than 2000 ideas and concepts [BMLFUW, 2017b]. The interministerial strategy intends to overcome sectoral and bureaucratic boundaries and serve systematic improvement of economic and living conditions for safeguarding the future of rural areas. Twenty fields of action were identified and listed - not in a hierarchical or priority order, sometimes overlapping and probably not all with the same importance. But in the view of those participating, they are seen as crucial for rural development:

- Decentralisation (shifting public administration, reduction of bureaucracy, e-government);

- Joint projects across municipalities (competence centres, inter-municipal financial compensation and tax splitting);

- $\quad$ Digitisation (adapted telecommunication, certified digital municipalities, competences, education);

- $\quad$ Resources (circular economy, renewable energy, innovation, bio-economy);

- $\quad$ Land use (regional planning, re-use, modernisation);

- Mobility (novel concepts for private and public transport, adapted settlement developments, adaptation of the tax system, network of providers);

- Healthcare (sector-integrating planning, family practices, e-health, prevention, cooperation between health professions);

- $\quad$ Taking care of the elderly (innovative models, flexible forms);

- $\quad$ Energy (energy saving, reduction of bureaucracy, renewable energy, harmonised policy, efficient climate protection); 
- Economic activity (regional chains, new rural entrepreneurs, multifunctional local supply, regional added-value, regional banks, cooperatives);

- $\quad$ Voluntary work (motivation, information);

- $\quad$ Social services (green-care services, social innovations);

- Women (incentives for qualified workplaces, compatibility of family and work-life, female business creation, online education);

- $\quad$ Education (lifelong learning, support in career decisions, better networking);

- Rural exodus (modern infrastructure, business creation, services for returning people, social networks, affordable housing);

- $\quad$ Tourism (reduction of bureaucracy, regional brands, culinary profiles, Alpine health and wellness, farm-based products);

- $\quad$ Childcare (improvement of childcare services for various ages);

- Regional strategies (tailor-made strategies, cross-sectoral priority topics, efficiency and efficacy in cooperation);

- $\quad$ Catering (Austrian culinary network, umbrella brand);

- $\quad$ Culture (regional strategies, incentives for creativity).

The implementation of such a strategy is a great challenge because the competences of various sectors and ministries, various political backgrounds and regional interests have to be coordinated, adapted and compromises have to be found. As the government and all of the ministers changed after the 2017 Austrian general election, there is the risk that the Master Plan and its efforts will become stuck in its initial phase. Nevertheless, it is a good basis for discussion about the design of the next period's CAP.

\subsection{CAP in the system of the EU policy objectives and in the view of regional science concepts}

For the current period of the EU structural policy, the Commission sought to create a consistent system of objectives, strategies and measures to generate synergies and greater efficiency. Contradictory objectives and activities were to be avoided. Smart, sustainable and integrative growth is, therefore, the overall priority in the Europe 2020 strategy. Below this level, more concrete objectives of employment, innovation, knowledge, social integration and climate/energy have been formulated. At a further subsidiary level, the common strategic framework comprises 11 thematic objectives and structures of the budget for the policy fields. This is the link to national strategic plans. Concerning agriculture and rural development, 3 objectives, 6 priorities and 18 focus areas at the EU level provide the framework for the national implementation of the CAP. This complexity and the vertical and horizontal links between objectives look good in 
theory, but are difficult to follow as regards implementation, and evaluation of the CAP measures and it is even more difficult to prove that each individual measure serves all the various objectives.

Conflicts in systems of strategies and objectives can occur on various levels. In principle, already on a very abstract level it has to be decided how to influence regional development. There are various approaches in regional science, which are subject to certain developments and contemporary trends. Neoclassical theories rely on balanced markets and seek to influence only to avoid certain disadvantages and disparities, in order to enable a "regionally justified" development [Eltges, 2013]. But the marginal utility of invested capital in this case, is not optimal [Bökemann, 1999]. Focus and hope rely on sum effects and long-term balanced developments. On the other hand, growth-pole theories [Gabler, 2015] count on efficient investment of limited budgets in e.g. "lighthouse" projects and hope for cumulative and spreading effects with the risk of increasing the regional disparities. The recent trends in regional development promise endogenous development approaches, regional circular economies, bottom-up initiatives, creating networks and providing incentives to foster knowledge transfer and innovation.

These considerations and the related regional development criteria have led to the following rough qualitative assessment of the CAP measures on the part of regional science criteria with the purpose of showing the great variety and diversity of strategies and measures. For example, the CAP comprises measures to preserve small farms and, on the other hand, measures to preserve big farms and to increase farm sizes. It includes measures to strengthen competitiveness, but at the same time it preserves uncompetitive structures through direct payments and small-farm supports. The CAP has objectives concerning social aspects, environmental aspects and economic aspects, but often they cannot be combined, if we think of terms like labour productivity or other efficiency criteria, in contrast to social measures. But objectives can also contradict each other within one of these sectors. For example, the positively rated renunciation of pesticides leads to increasing mechanical processes, which, unfortunately, cause additional greenhouse-gas emissions and may increase the risk of soil erosion. Specifically targeted measures, but also broad all-around measures exist. Some examples of regional science concepts and their related CAP measures are listed here:

- Balancing development strategy versus growth-pole-oriented strategy: market organisation payments have a balancing effect while the support for quality schemes seems to follow growth-pole theory.

- $\quad$ Concerning the path-development (continuing, renewal, new creation of paths): the first pillar measures clearly support the continuation of historic 
paths, while measures supporting knowledge transfer or investments stand for the renewal or creation of new paths.

- In case of sustainable development considerations, all three aspects (economics, ecology, social aspects) are in focus. But per definition they cannot always steer in the same direction. There are environmental payments, and, on the other hand, market organisation payments and support for investment that focus directly on economic benchmarks. And in contrast local development subsidies often foster social aspects.

- $\quad$ Most of the CAP measures seem top-down driven (e.g. direct payments, investment support), only a few follow a bottom-up approach (community-led local development or partly the European innovation partnership).

- The payments to areas facing natural constraints support regional convergence, while for example environmental payments can lead to greater divergence.

- $\quad$ Direct payments or market organisation payments, payments to areas facing natural constraints have a clear structure-preserving effect, while the support for knowledge transfer or farm and business development may have structure-changing effects.

- $\quad$ Some measures take effect in the direction of agricultural monostructures (mostly pillar-one measures) others have diversification as an explicit objective (e.g. Natura 2000 and the Water Framework Directive payments).

- Many of the measures can be used to strengthen the market power of farmers, but there are also some with no or negative influence on the market power of farmers in relation to the food processing industry or food trading companies.

\subsection{Summary and conclusions}

There is no clear evidence whether or not the one or other theoretical basis leads to success in regional development. The above list is not intended as classification of good or bad. It should raise the awareness that among so many objectives and measures in such a wide variety of theoretical approaches the risk of conflicts or contradictory impacts is very high. Specific societal objectives are per se divergent, and compromises have to be found. Sometimes a specific regional situation or a current political issue acts as a trigger for measures that do not fit into a given theoretical concept. For example, the objective of a regional circular economy is to strengthen autonomy and resilience and minimise transport and $\mathrm{CO}_{2}$ balances. But it can also be seen that if it seems economically promising, exports to most distant regions are also supported. Conflicts of objec- 
tives are also addressed in Commission papers [European Commission, 2013]: while payments for market organisation hinder the development of competitiveness, other measures explicitly support the competitiveness of farm enterprises. In reality the CAP is a large system of historically developed and grown strategies and measures that do not pursue just one objective or theory. It is relatively easy (assuming no budget constraints) to introduce new measures but enormously difficult to drop measures against the will of lobbies. There is the risk of prolonging existing payments with new justifications, as is discussed by Tangermann [2014] using the example of direct payments. In every case the strategies and measures have to be very well adapted to specific regional situations, bearing in mind not only the effects on farmers and rural areas but also the effects on potential shifts of regional competitiveness and rankings. The notion of "agricultural" policy can be misleading when analysing all the objectives and measures. In reality it comprises general economic, environmental and social policy. Probably it would be more transparent to change the title of this policy.

\section{References}

1. BMLFUW - Federal Ministry of Agriculture, Forestry, Environment and Water Management (2017a). Green Report, Vienna.

2. BMLFUW-Federal Ministry of Agriculture, Forestry, Environment and (2017b). Master Plan for Rural Areas, Vienna.

3. Bökemann, D. (1999). Theorie der Raumplanung (Theory of Spatial Planning), Munich, Vienna, Oldenburg.

4. Eltges, M. (2013). Regionale Konvergenz und Divergenz (Regional Convergence and divergence). Informationen zur Raumentwicklung 1/2013. Bundesinstitut für Bau-, Stadt- und Raumforschung, Bonn. Retrieved from: http://www.bbsr.bund.de/BBSR/DE/Veroeffentlichungen/IzR/2013/1/Inhalt/DL Eltges.pdf?_blob=publicationFile\&v=2 (accessed om: 16.2.2015).

5. European Commission (2013). Agricultural Policy Brief No 9. Retrieved from: http://ec.europa.eu/agriculture/policy-perspectives/policy-briefs/09_en.pdf (accessed on: 11.2.2014).

6. Gabler Wirtschaftslexikon (2015). Springer. http://wirtschaftslexikon.gabler.de/ Definition/wachstumspoltheorie.html (accessed on: 16.2.2015).

7. Tangermann, St. (2014). Direktzahlungen: ein bleibender Bestandteil der EUAgrarpolitik? (Direct Payments: a consistent part of EU-CAP?), in Schmid E., Vogel St. (ed.) Europäische Agrarpolitik im 21. Jahrhundert, Vienna, Facultas.

8. Trippl, M. et al. (2015). Regionale Pfadentwicklung in der Wissensökonomie (Regional Path Development in the Knowledge Economy), in Geographische Rundschau 12/2014, Braunschweig, Westermann, pp. 32-36. 